\title{
EXPLANATORY FACTORS FOR THE VARIATION IN HOSPITALIZATIONS ${ }^{1}$
}

\author{
Lucieli Dias Pedreschi Chaves ${ }^{2}$
}

Maria Luiza Anselmi ${ }^{3}$

Chaves LDP, Anselmi ML. Explanatory factors for the variation in hospitalizations. Rev Latino-am Enfermagem 2008 março-abril; 16(2):287-92.

In the implementation/consolidation process of the Brazilian Single Health System (SUS), hospitalization deserves special attention from the local management. This descriptive study identifies, through qualitative data, factors that explain variations in the number of hospitalizations processed and paid by the Municipal Health Department of Ribeirão Preto, Brazil. Data were collected through interviews with people who produce/use information regarding hospitalizations and then analyzed according to Bardin's (1979) thematic content analysis. As the major explanatory factors for the variation in hospitalizations, interviewees indicated changes in the demographic structure, low problem solving ability in basic care services, introduction of hospitals in the health system, technological incorporation, and the administrator's role in the local health system. It is the responsibility of the administrator, by using scientific instruments associated to human interaction, to regulate, control, and evaluate hospitalizations, planning health care according to the users' needs and organizing the system so as to reach satisfactory results.

DESCRIPTORS: health manager; hospitalization; single health system; hospital information systems

\section{FACTORES QUE EXPLICAN LA VARIACIÓN EN EL NÚMERO DE HOSPITALIZACIONES}

En el proceso de implementación/consolidación del Sistema Único de Salud (SUS), el control en el número de hospitalizaciones merece una atención diferente por parte del gestor local. Este estudio descriptivo, parte de datos cualitativos, identifica factores que explican la variación en el número de hospitalizaciones registradas y pagadas por la Secretaría Municipal de Salud de Ribeirão Preto-SP. Los datos recolectados a través de entrevistas con los sujetos que contabilizan/utilizan informaciones relacionadas a las hospitalizaciones; datos que fueron analizados según el análisis temático de Bardin (1979). Cambios en la estructura demográfica, poca capacidad resolutiva de los servicios básicos, participación de los hospitales en el sistema de salud, incorporación tecnológica y rol del gestor en el sistema local de salud; fueron factores indicados por los entrevistados con relación a las variaciones en el número de hospitalizaciones. El gestor, utilizando instrumentos científicos asociados a la interacción humana, es responsable por regular, controlar y evaluar el número de hospitalizaciones; planificando la atención de salud de acuerdo a las necesidades del usuario y estructurando el sistema para el alcance de resultados satisfactorios.

DESCRIPTORES: gestor de salud; hospitalización; sistema único de salud; sistemas de información en hospital

\section{FATORES EXPLICATIVOS PARA A VARIAÇÃO NA PRODUÇÃO DE INTERNAÇÕES HOSPITALARES}

No processo de implementação/consolidação do Sistema Único de Saúde (SUS), o acompanhamento da produção das internações hospitalares deve merecer atenção diferenciada da gestão local. Este estudo descritivo, a partir de dados qualitativos, identificou fatores explicativos para a variação na produção de internações hospitalares processadas e remuneradas pela Secretaria Municipal de Saúde de Ribeirão Preto, SP. Os dados, coletados em entrevistas com sujeitos que produzem/utilizam informações pertinentes às internações hospitalares, foram analisados segundo a análise temática de Bardin (1979). Mudanças na estrutura demográfica, baixa resolutividade dos serviços básicos, inserção dos hospitais no sistema de saúde, incorporação tecnológica, papel do gestor no sistema local de saúde foram os fatores explicativos apontados pelos entrevistados para a variação na produção de internações. Cabe ao gestor, utilizando instrumentos científicos associados à interação humana, regular, controlar e avaliar a produção de internações, planejando a atenção à saúde, conforme as necessidades dos usuários, ordenando o sistema para atingir resultados satisfatórios.

DESCRITORES: gestor de saúde; hospitalização; sistema único de saúde; sistemas de informação hospitalar

${ }^{1}$ Article extracted from Doctoral Dissertation; ${ }^{2}$ PhD, Faculty, e-mail: dpchaves@eerp.usp.br; ${ }^{3}$ RN, Associate Professor, e-mail: anselmi@eerp.usp.br. University of São Paulo at Ribeirão Preto, College of Nursing, WHO Collaborating Centre for Nursing Research Development, Brazil 


\section{INTRODUCTION}

The supervision of the produced hospitalizations should receive special attention, not only due to the quantity and variety of material and human resources they consume, but also to the possibility of the administrator to structure basic care and reorganize the local health system.

The Basic Operational Rules of the Single Health System - SHS (Sistema Único de Saúde - SUS), the NOB-SUS 01/96 and NOAS 01/01, in particular, reinforce the definition of the government's roles. The responsibility for basic care is assigned to the city; whereas secondary, tertiary, and high cost/complexity care are a responsibility of the state and government, mainly in terms of their financing.

Organized and systematized information is essential for administrators to support/improve the decisions that constitute the work process. This is particularly true regarding hospitalization information obtained in the Hospital Information Systems - SUS (SIH-SUS), which constitute an accessible and relevant tool for the continuous supervision of this expressive segment of the local health system.

The study of hospitalizations is a priority in the present Brazilian scenario, which is characterized by its intense and poorly regulated technological incorporation in the health area. This results in growing expenses in the sector, due to increased case complexity and growing hospitalization expenses. Furthermore, this scenario is also marked by the crisis in hospitals attending the SHS, due to non-professional management and budget imbalance. (1)

A study about the physical and financial production of hospitalizations by the SHS found a general increase of $56 \%$ in paid hospitalizations, and $156.3 \%$ in the amount spent on the respective payments, in five hospitals associated with/contracted by the SHS, under municipal administration in Ribeirão Preto - SP, from 1996 to 2003. Both increases were higher than those found in the state of São Paulo and Brazil. (2)

This result aroused the following question: What factors/elements cause/explain this variation in the production of hospitalizations? The present study was developed based on this question, believing that the obtained answers would be able to contribute to understand, in a broad way, the dynamics of hospitalization production in the health system of Ribeirão Preto, as well as to suggest some interventions.

\section{PURPOSE}

The purpose of this study was to identify and describe explanatory factors for the variations in the dynamics of the hospitalizations processed and paid by the Municipal Health Department, from 1996 to 2003, according to the reports by people who produce/ use hospitalization data in Ribeirão Preto-SP.

\section{METHODOLOGY}

This is a descriptive and exploratory research, with a qualitative approach, developed in the city of Ribeirão Preto, in the Northeast region of São Paulo, more specifically in the Municipal Health Department (SMS-RP), which is in charge of hospitalizations management in the five hospitals associated with/contracted by the SHS.

The study period (1996-2003) was chosen because it corresponds to the beginning of the city's qualification process to establish a semi-comprehensive management system. At that moment, the city took on the responsibility for managing the local health system, including the evaluation and control of the production and invoicing of providers contracted by/ associated to the SHS, through SIH-SUS and the Outpatient Information System (SIA-SUS); the registration, health service hiring and implementation of the rules proposed by the Health Department.

The subjects of this study were people who, in the local health system, somehow produced/used information regarding hospitalization for the purpose of evaluation, audit, control and decision making, concerning the distribution of the Hospitalization Authorization (AIH) and the use of financial resources. Based on the criteria and reasons given, 18 subjects were selected to participate in the study: two administrators, five representatives of the health service providers, six representatives of the users in the Municipal Health Council (CMS), four auditors from SMS-RP and one representative from the Planning Division of SMS-RP.

The technique used for data collection was semi-structured interview. A script containing questions and graphs was used for guidance, exemplifying the physical and financial production of hospitalizations in the five hospitals contracted by/ associated to SMS-RP, according to the results obtained in the previous study ${ }^{(2)}$. 
This script was validated and submitted to a pre-test. It consisted of two parts: one part for subject identification, and the other to request, through the presentation of production graphs, the identification of the possible explanatory factors for the variation (increase/reduction) in the hospitalizations from 1996 to 2003.

The interviews generated 12 (twelve) hours of recordings, with an average of 45 minutes each. The statements were fully transcribed and the texts were checked with their recordings, so as to guarantee reliable reproduction. They were then edited, removing language vices and parts that could identify the referred people/institutions. In the results, the reports are referred to using the letter I (interviewee) and sequential numbers from 1 to 18 , for instance, code I1 corresponds to Interviewee number 1 , and so on.

Data analysis was performed using Thematic Content Analysis (3), starting with the impregnation process, followed by exploratory, vertical and exhaustive material reading. After that, a horizontal reading of the statement groups was performed, to permit relations between the statements. During the horizontal and vertical reading processes of the interviews, thematic groups were identified and analyzed in the light of the theoretical reference framework. In the following stage, the resumed analysis of each report was elaborated, identifying aspects pertinent to the thematic groups, and, finally, the resumed analysis of the statement groups took place.

Compliance with the rules established in National Health Council Resolution 196/96 (4) was assured in the development of the study.

\section{RESULTS}

The thematic groups identified in the interviewees' statements comprised the explanatory factors for the variation found in the production of hospitalizations. These included: low problem-solving ability of primary health care services, introduction of associated/contracted hospitals into the local health system, technological incorporation, changes in the demographic structure and the role of the administrator in the local health system, particularly concerning control, evaluation and regulation aspects.

The organization and preparation of the local health system, in order to solve problems pertinent to each complexity sphere, is the responsibility of the administrator. Nevertheless, one of the reasons pointed out for the increase in hospitalizations was the low problem-solving ability in the basic and secondary health services:

We have a very large network; I don't mean that hospitalizations could be avoided, because some cases in the surgical and emergency area really belong in the hospital. However, many situations can be controlled by the basic network to prevent people from getting seriously ill and then require hospitalization (I 1).

Our basic network forwards... sends patients to the hospital, this ends up generating a great number of hospitalizations in situations that could be solved even in the primary or secondary level. there is often a lack of structure or interest to keep this patient under observation, which generates hospitalization (I 15).

Considering that structuring or installing new health units alone is sufficient and able to assure that the population's health problems are solved at the primary and secondary care level and, consequently, that this measure by itself reduces the number of hospitalizations, would be a narrow analytic perspective.

Based on the situational diagnosis of the population's social-epidemiological-economic conditions and of the available resources, it is important to predict problems and situations that can be dimensioned by readjusting the services provided. This would provide health care with human, material, and instrumental capability, within a logic that is more preventive than healing and, also, more collective than individual.

The pyramidal model of health care still has not reached results that meet the population's health needs, even though it has led to significant changes in the structures and work processes in health care. Health care coverage has been insufficient, as well as the complementarity and integration of actions at the different health care units, generating imbalance in the relationship between service supply and demand. Added to the lack of political definitions, low problem- solving ability, and poor quality offered by the services, this leads to a greater search for medical care in emergency hospital services, which corresponds to the profile of answering demands in a faster and concentrated way ${ }^{(5)}$.

Based on the context above, it is understood that there is a need to re-dimension the role/function of the hospital in the local health system. This does not mean the hospital should be replaced or its importance 
reduced, but rather that its role should be adapted to those cases in which the complexity or urgency are justified, following the same logic of the SHS, especially regarding doctrinal and administrative principles.

The introduction of associated/ contracted hospitals in the local health system does not always comply with the logic established by the SHS. Besides, they often work to guarantee their own interests, as illustrated by the following statement:

The provider can practically act according to his institutional development policy, handling certain demands that are more profitable against the interests of others less profitable, or, even the natural difficulty, that they look for this course as a businessman. Therefore, it is the administrator's responsibility to harmonize the development of these institutions with the needs of the city (I 13).

The expressed view suggests the need for a better integration/articulation of the hospitals associated with/contracted in the local system, in order to permit better knowledge regarding these services' roles. The quantitative and financial aspects of these hospitals' participation and the production of hospitalizations need to be controlled/regulated/ evaluated, providing the people involved in the process with this information.

The interviewees also stated that the technological incorporation is an explanation for the increase in the number of hospitalizations. They considered this in terms of the availability of therapeutic as well as diagnostic resources, which allow for improvements in users' living conditions, as well as in the context of providers, which adapt their structure in order to offer more specialized services and, thus, increase revenues, as exemplified by the statements below:

Procedures with very suitable financial amounts were created, and this enabled the hospital to get specialized in this kind of procedure; leaving others behind, which, according to them, cause losses (I 12).

There was great improvement in patient health care. Consequently, whenever there are improvements in patient care, investments also evolve into greater expenses (I 9).

During the study period, the city incorporated technological resources related to therapy and diagnosis, such as computerized tomography, magnetic resonance, stant use, electrophysiological studies in cardiology, biventricular pacemaker, implementation of the Urgency Mobile Health Care Service (SAMU), surgery by video laparoscopy, and others.
The importance of technological advances is unquestionable. Nevertheless, for the survival of the health system, it is pertinent and appropriate to increase comprehensive alternatives, which involve light technologies, different care models, incentives to collective actions and allow the rational use of the available financial resources. Likewise, it is necessary to evaluate the incorporation of new technologies in a broad sense, considering cost-effectiveness and health care coverage for the population as a whole.

The changes in the demographic structure of the city population regarding growth and aging were also indicated as a possible explanation for the variation in the production of hospitalizations:

The population growth consequently increases the demand for hospitalizations and the search for hospitals (I 9).

It is also obvious that you consider the matter of profile change, of demographic and epidemiologic profiles, justifying some types of procedures that started to increase; the population is getting older, and generally, elderly people demand greater expense (I 6).

During the study period, the city population increased by $15.7 \%$. The population covered by the eighteenth regional health district increased by $14.5 \%$ and the production of hospitalizations in this period by $56 \%$. This showed a percentage variation much higher than that of the population ${ }^{(6)}$.

In Ribeirão Preto, in 1996, the proportion of people under 15 years old was $26.4 \%$, against $24.6 \%$ in 2003. The percentage of people over 60 years old in 1996 was around $9.4 \%$ and, in 2003, it rose to $10.1 \%$. These data indicate a tendency of reduced birth rates and an increase in the percentage of elderly people ${ }^{(5)}$

The aging situation and the increased demand for financial and technological resources put pressure on the local administration regarding the implementation of preventive actions specifically aimed at the elderly, as well as other health care methods than hospitalization, such as home care and day-hospitalization.

Supervising and inspecting the financial resources spent every month for each hospital provider and the respective production, articulated to other health care spheres in the city, permits the comparison of local indicators and the adoption of pertinent measures. In this context, the reports refer to the role of the administrator, in terms of the use of management tools, which are: control, evaluation and regulation of the local health system. 
The expectation that administrators play their role in system control, regarding hospitalizations, indicates the need to establish patient flow, localregional references and production goals, which are important outlines in the coordination of the health system. This is verified in the statement below:

It is the responsibility of the administrator to control this in a more homogeneous way, (...) these cases of major complexity that arrive at the hospital. There is great difficulty to control these cases, because most of them are forwarded as medical urgency and emergency cases (I 12).

Associated to the control, the evaluation may allow for a broader view of the hospitalization production in the local health system, as shown by the following report:

You obviously understand that these procedures were performed, but are they necessary for the population? Do we work with these procedures aiming for the provider's interest in profit and its performance, instead of health planning? Is it a need of the city population? I believe that this type of evaluation, considering the need, does not exist. It is very complicated to make this type of evaluation. You end up doing something afterward; you cannot do something in advance. Maybe we need some of this evaluation, a bit more detailed so that you can make a more suitable health care planning (I 6).

Evaluation is focused on as a device to estimate the impact of hospitalization expenses on population health; identify the possible reasons for the differences between the physical and financial production in the different areas; monitor the events in order to predict the problems and suggest suitable interventions. Regarding the hospitalization, articulated with control and evaluation, the system regulation favors management capability, as observed in the report below:

Our big problem is the distribution among providers; it would be better dimensioned if the population needs were associated to the available resources, in either one or several hospitals. The regulation method is important, we are going to make this patient, who needs this service, reach the providers; what the administrator needs is to address this issue in a regular way, this is the key (I 12).

In order to regulate the local system, it is not enough to organize the flow of users, even though this is an essential stage. It is necessary to know the health demands and service availability. The report above evidences a certain lack of knowledge about the city's actual health situation, available resources, existing demands and the method to balance supply/ needs.
Although control and evaluation are prerogatives to assume the different management methods since NOB 93, in a general way, they are still underexplored management tools in the local system's decision-making processes. The system regulation, another management tool, has been recently incorporated into the SHS, more specifically after NOAS 01/01. Despite its incipient stage, its use will offer positive contributions to the management process, aiming to regulate and control the entire localregional health care availability; speed up health care in order to provide the user with more comfort; help the control of the demand flow and health care possibilities; and distribute health resources more equally to the population according to their needs. (7)

The increase in management efficiency and efficacy, more specifically of hospitalization, is meaningful when aiming to improve user health care. This improvement involves aspects likehealth care humanization, the adoption of measures that meet the increasing demands and needs of the population, as well as the use of instruments for making strategic decisions. This is done to generate knowledge and promote management integration among the different levels of the system and their respective participants, articulating the entire process to the rational use of the financial resources available.

\section{FINAL CONSIDERATIONS}

The production of hospitalizations represents an important part of health care in the city, due to both its complexity and to the financial amount spent. The variation in the production of hospitalizations deserves a critical and attentive look by the people who manage the system and who produce hospitalization data.

From the interviewees' point of view, the variation in the production of hospitalizations results from aspects related to: low problem-solving ability by the basic health care network, which determines spontaneous search and/or the forwarding to more complex services; changes in the population profile concerning growth, aging and morbidity-mortality patterns; technological incorporation that generates new costs and expenses; low efficiency of inspection, control, audit, evaluation and regulation actions.

The authors understand that, based on the analysis of the obtained results, it is necessary to 
join forces among the management, evaluation and control areas, providers and users, in order to (re)structure the local health system, sureveying limitations, possibilities and alternatives for the rational use of the health care resources the population has at its disposal in the field of hospitalization.

\section{REFERENCES}

1. Castro MSM, Travassos C, Carvalho MS. Fatores associados às internações hospitalares no Brasil. Ciênc e Saúde Coletiva 2002 outubro; 7(4):795-811.

2. Chaves LDP. Produção de internações nos hospitais sob gestão municipal em Ribeirão Preto-SP, 1996-2003. [tese]. Ribeirão Preto (SP): Escola de Enfermagem de Ribeirão Preto/ USP; 2005.

3. Bardin L. Análise de conteúdo. Lisboa: Edições 70;1979.

4. Ministério da Saúde (BR). Diretrizes e normas regulamentadoras de pesquisa envolvendo seres humanos. Brasília (DF): Ministério da Saúde; 1997.

5. Marques GQ, Lima MADS. Demandas de usuários a um serviço de pronto atendimento e seu acolhimento ao sistema de saúde. Rev Latino-am Enfermagem 2007 janeiro-fevereiro; 15(1):13-9.

6. Ministério da Saúde (BR) [homepage na internet]. Rio de Janeiro: DATASUS; [Acesso em 2005 abril]. Produção hospitalar; [6 telas]. Disponível em: http:// tabnet.datasus.gov.br/cgi/deftohtm.exesih/cnv/rxsp.def 7. Ministério da Saúde (BR). Secretaria de Assistência à Saúde. Portaria n.0 423, de 09 de junho de 2002. Estabelece atribuições básicas de controle, regulação e avaliação no SUS. Brasília (DF); 2002. 